\title{
Enhancement the Suppressive Effect of Date Palm Leaves Compost (DPLC) against Faba Bean Wilt with Plant Growth Promoting Rhizobacteria (PGPR) M.F. Abdel-Monaim
} Legume and Forage Crop Dis. Res. Dep., Plant Pathol. Res. Inst., ARC, Egypt.

\begin{abstract}
This study deals with in vitro, greenhouse and field efficacy of plant growth promoting rhizobacteria (PGPR) strains and date palm leaves compost (DPLC) for controlling faba bean wilt caused by Fusarium oxysporum. Date palm leaves compost at 2,4,6,8,10 ton/feddan significantly decreased wilt severity under artificial inoculation with Fusarium oxysporum in pot and the natural infection in the field, as well as increased growth and yield parameters during 2013/2014 growing season. Date palm leaves compost at 8 ton/feddan recorded the highest protection against faba bean wilt as well as gave the highest increase of plant growth and yield parameters. On the other hand, PGPR, viz. Bacillus megaterium, B. cereus and Pseudomonas fluorescens individually or in combination significantly increased the efficacy of DPLC for controlling Fusarium wilt of faba bean more than application of DPLC alone under greenhouse and field conditions during both growing seasons (2014/2015 and 2015/2016) as well as increased nodulation, plant growth and yield parameters. Application mixture of PGPR strains together with DPLC at 8 ton/feddan recorded the highest reduction to wilt severity with the highest increase of nodulations, plant growth and yield parameters.
\end{abstract}

Keywords: Date palm leaves compost (DPLC), faba bean, Fusarium wilt, growth and yield parameters, nodulation and PGPR.

Faba bean (Vicia faba L.), family Fabaceae is considered the most important nutritive popular food crop in the world and in Egypt. It plays a major role in the Egyptian diet as a cheap source of protein. Faba bean crop is rich in protein (protein content ranges from 26 to $41 \%$ ) and the supply of essential amino acids (Fernández et al., 1996). Several investigators recorded that diseases found on faba bean are considered the most destructive and cause considerable losses in yield (El-Bramawy and Shaban, 2010 and Mahmoud, 2016).

Fusarium wilt caused by $F$. oxysporum f. sp. fabae has become serious in recent years and it is considered one of the main constraints for faba bean production in Egypt, especially in the new reclaimed soil (Abdel-Monaim, 2013 and 2017). In view of difficulties and problems associated with chemical control of soil borne plant pathogens and environmental pollution, employment of bio-control agents for plant disease management is considered as a good alternative. However, more attention has been given to plant growth promoting rhizobacteria (PGPR), as the most important alternative to chemicals, to help eco-friendly biological control of soil borne pathogens 
(Heydari and Pessarakli, 2010). The potential of PGPR to protect plant roots from soil borne pathogens was demonstrated in several research works (Abdel-Monaim, 2017). The author found that inoculation of faba bean with PGPR strains significantly reduced wilt diseases either under artificial infection in pot experiments or natural infection in the field and also enhanced nodulation status in the roots, as well as increased plant growth.

On the other hand, suppression of these plant pathogens is considered an urgent need for present agriculture practices. Therefore, the use of compost to suppress the wilt pathogen has been extensively reviewed by many workers (Muhammad et al., 2001 and Sabet et al., 2013). Composted organic material such as plant debris and animal manure add nutrients to the soil, thereby increasing the soil fertility. This improves plant growth and makes the plant less prone to infection by pathogens. Organic substrates had been reported to have lower bulk density. It has also been reported to provide adequate nutrients to the seedlings and reduces their predisposal to soil borne pests and diseases (Bonanomi et al., 2007). Different mechanisms were suggested to explain the role of compost application to control wilt disease such as enhancement beneficial microorganisms which secrete lytic enzymes and antibiotics, containing microorganisms which competed for nutrients, or activation of disease-resistance genes (induce resistance) in plants (Litterick et al., 2004).

The effect of compost on disease suppression is thought to be through a combination of microbial competition, referred to as general suppression, and effects of specific antagonists through commensalism, hyperparasitism or induced resistance, generally referred to as specific suppression. The reliability of compost in suppressing disease can be increased by combining it with a biocontrol agent (Hoitink and Boehm, 1999). ElMougy et al. (2014) found that the combined treatments between mixture of animal plus plant compost and Trichoderma harzianum were more effective for suppressing lupine root rot under field conditions than the used alone on them. Abdel-Razik et al. (2012) found that the combined Planta Rich and Rich Composts (CMs) treatments with yeast seed treatment increased the suppressive effect of CMs on faba bean root rot and wilt severity under greenhouse and field conditions. El-Wakil et al. (2009) reported that common seed-borne fungi of faba bean can be controlled by the seed treatment with bread yeast before sowing in the soil supplemented with two types of composts.

The aim of this work was to study the effect of combined application of suppressive date palm leaves compost (DPLC) to soil and seed treatment with some plant growth promoting rhizobacteria (PGPR) on the control of faba bean wilt caused by $F$. oxysporum as well as their effect on plant growth and seed yield.

\section{Materials and Methods}

Source of fungal pathogen:

A pathogenic isolate of $F$. oxysporum isolated from diseased faba bean plants, collected from New Valley Governorate (Abdel-Monaim, 2017) was used in this study.

Preparation of fungal inocula:

The inocula of $F$. oxysporum were prepared from one week old culture grown on 50 $\mathrm{mL}$ potato dextrose broth (PDB) medium in conical flask $(250 \mathrm{~mL})$ and incubated at 25

Egypt. J. Phytopathol., Vol. 45, No. 1 (2017) 
$\pm 1^{\circ} \mathrm{C}$. The content of the flask was homogenized in a blender for one min. Plastic pots were filled with sterilized soil mixed with the fungus inocula at the rate of $100 \mathrm{~mL}$ homogenized culture per pot, seven days before planting (Abdel-Monaim, 2013).

Preparation of plant growth promoting rhizobacteria (PGPR) strains:

Strains of Bacillus megaterium, B. cereus and Pseudomonas fluorescens were cultured individually in nutrient broth medium in $250 \mathrm{ml}$ flasks and incubated at $25 \pm 1$ ${ }^{\circ} \mathrm{C}$ for $48 \mathrm{~h}$, then a cell suspension of each strain was adjusted to provide $2.5 \times 108$ $\mathrm{cfu} / \mathrm{ml}$ (Abdel-Monaim, 2013 and 2017).

Preparation of date palm leaves compost (DPLC):

Date palm leaves compost was prepared according to the method described by AbuAlfadhal (1970) with some modification described by Ali (2011).The dried date palm leaves (DPL) were chopped into $10 \mathrm{~cm}$ segments and buried in $2 \times 1 \mathrm{~m}$ size concrete pit with a $1.1 \mathrm{~m}$ depth. The compost layers were built in such way that each layer was about $25 \mathrm{~cm}$ deep. First, a layer of $96 \mathrm{~kg}$ of dried date palm leaves were placed in the bottom and then, the desired quantity of a mixture of ammonium sulfate, trisuper phosphate, fine $(100 \mu)$ calcium carbonate and clay in a ratio of 35:7:35: $100 \mathrm{~kg}$, respectively, per ton of dried date palm leaves were distributed homogeneously. Each layer was sprayed with $77 \mathrm{~L}$ of water having a total salinity of $640 \mathrm{mg} \mathrm{L}-1$ total dissolved solids (TDS). In all, there were 4 identical layers of DPL, making the total depth of DPL up to $1 \mathrm{~m}$ in height. The compaction of date palm leaves was done manually at the time of making each compost layer for proper decomposition. Initially, the compost layers were stirred after six weeks followed by remixing the compost layers with an interval of 3-weeks. After 6-months, the compost pit was opened. The completely decomposed date palm leaves (compost) were separated from the undecomposed part of date palm leaves, which was mainly the hard mid-rib of the palm leaves. The decomposed portion of the date palm leaves (compost) was used in the experiments. The analysis of the tested CMs was done by the Central Laboratory of Soil and Water Dep., El-Kharga Agric. Res. Stat. (Table 1).

\section{Greenhouse experiments:}

Effect of different concentrations of date palm leaves compost (DPLC) on wilt severity:

The experiments were conducted at the New Valley Res. Stat. under greenhouse conditions using Masr1 faba bean cultivar. Date palm leaves compost (DPLC) was added to the soil in pots ( $30 \mathrm{~cm}$ in diam., containing $5 \mathrm{~kg}$ soil) at rates equivalent to 2 , 4, 6,8 and 10 ton/feddan (feddan $=4200 \mathrm{~m}^{2}$ ) in a pot experiment for evaluating the suppressive effect of DPLC alone on the pathogen. Soil was infested with $F$. oxysporum at the rate of $100 \mathrm{~mL}$ homogenized culture per pot prepared as mentioned before. Untreated infested pots were used as a control. All pots were irrigated 7 days before planting to enhance fungal growth and to ensure even distribution of the inocula. Surface sterilized faba bean seeds (cv. Misr 1) were sown at the rate of 5 seeds per pot. Four pots were used as replicates for each treatment. Pots were irrigated as needed. All pots were examined 90 days after sowing to record the percentage of wilt severity. 
Table 1. Characteristics of date palm leaves compost used in this investigation

\begin{tabular}{|l|c|}
\hline \multicolumn{1}{|c|}{ Analysis } & Value \\
\hline Weight of $\mathrm{m}^{3}$ & $600 \mathrm{~kg}$ \\
\hline Moisture (\%) & 27.00 \\
\hline $\mathrm{pH}(1: 10)$ & 8.38 \\
\hline $\mathrm{EC}(1: 10)$ & $3.45 \mathrm{DS} / \mathrm{m}$ \\
\hline Total nitrogen (\%) & 0.90 \\
\hline Organic substances (\%) & 26.97 \\
\hline Organic carbon (\%) & 14.64 \\
\hline C:N ratio & $17: 37$ \\
\hline Total phosphorus (\%) & 0.79 \\
\hline Total potassium (\%) & 0.94 \\
\hline
\end{tabular}

\section{Disease assessments:}

Disease severity was estimated after 90 days from planting as a wilting percentage, on the basis of root discoloration and leaf yellowing. Plants with typical Fusarium wilt symptoms were assessed according to the type of symptom that was observed using a numerical grades ranging from 0 to 5 according to Abdel-Monaim (2013) as follows: $(0)=$ No visible symptoms; $(1)=1 \%$ to $<20 \%$ of plant leaves are yellow and of the vascular systems are light brown (discoloration); $(2)=20-<40 \%$ of plant leaves are yellow and of the vascular systems are brown (discoloration); (3) $=40 \%$ to $<60 \%$ of plant leaves are yellow and of the vascular system are dark brown (discoloration); (4) $=60 \%$ to $<80 \%$ of plant leaves are yellow and of the vascular systems are dark brown (discoloration); $(5)=80 \% \leq 100 \%$ of plant leaves are yellow and of the vascular systems are dark brown (discoloration) or completely dead plants. Disease severity index (DSI) described by Liu et al. (1995) was adopted and calculated as follows:

$\mathrm{DSI}=\Sigma \mathrm{d} /(\mathrm{d} \max \times \mathrm{n}) \times 100$

Where: $d$ is the disease rating of each plant, $d$ max the maximum disease rating and $n$ the total number of plants/samples examined in each replicate.

Effect of soil amendment with date palm leaves compost (DPLC) alone or in combination with seed treatment with the PGPR strains on the severity of wilt:

In this experiment, the highly effective concentration of DPLC in pot experiment was used ( $8 \mathrm{ton} /$ feddan). Plastic pots $(30 \mathrm{~cm}$ in diam.) filled with soil mixed with DPLC (equivalent 8 ton per feddan) and infested with $100 \mathrm{~mL}$ homogenized culture per pot prepared as mentioned before, each of $F$. oxysporum then irrigated and left 7 days before sowing.

Faba bean seeds were soaked in PGPR strains for 12 hrs. viz. B. megaterium, B. cereus, $P$. fluorescens and their mixture and were individually sown in pots containing, either infested soil+ DPLC or infested soil only. The treatments were prepared as follows:

1. Untreated seeds sown in pots containing infested soil (control treatment)

2. Seed treated with $B$. megaterium and sown in pots containing infested soil

3. Seed treated with $B$. cereus and sown in pots containing infested soil

4. Seed treated with $P$. fluorescens and sown in pots containing infested soil

5. Seed treated with PGPR mixture and sown in pots containing infested soil

Egypt. J. Phytopathol., Vol. 45, No. 1 (2017) 
6. Seed treated with B. megaterium and sown in pots containing infested soil + DPLC

7. Seed treated with B. cereus and sown in pots containing infested soil + DPLC

8. Seed treated with $P$. fluorescens and sown in pots containing infested soil + DPLC

9. Seed treated with a mixture of PGPR and sown in pots containing infested soil + DPLC

10. Untreated seeds sown in pots containing infested soil+ DPLC

Four pots were used as replicates for each treatment, and five seeds were sown in each pot. The wilt severity was recorded as mentioned before.

\section{Field Experiments:}

Two experiments were implemented in New Valley Agric. Res. Stat. during season $2013-2014$ in case of the first experiment and during two successive seasons of 20142015 and 2015-2016 in case of the second experiment. Both experiments were applied in a field naturally infested with the causal of wilt disease. The field was divided into $3 \times 3.5 \mathrm{~m}^{2}$ plots. Each unit included 5 rows; each row was $3.5 \mathrm{~m}$ in length and $60 \mathrm{~cm}$ width. In the first experiment, DPLC was applied at the rate of 2, 4, 6, 8 and 10 ton /fed. to the prepared field plots before sowing. Faba bean seeds (cv. Misr 1) were sown in hills $25 \mathrm{~cm}$ apart on both sides of $6 \mathrm{~cm}$ ridges, 2 seeds per hill, in plots amended, or not, with DPLC. In case of the second experiment, the tested DPLC was applied at the rate of 8 ton/fed to the prepared field plots before sowing. Faba bean seeds (cv. Misr 1) treated, or untreated, with PGPR strains, viz. B. megaterium, B. cereus, P. fluorescens and a mixture of them (as mentioned before) were sown in plots amended, or not, with DPLC. The experiment was arranged in a complete randomized block design with three replicates.

In control treatment, faba bean seeds were soaked in water for $12 \mathrm{hr}$ and sown at the same rate. The normal cultural practices of growing faba bean were followed. Wilt severity for each replicate was calculated as mentioned before.

Number and dry weight of nodules per plant were recorded 60 days after sowing. At harvest, plant height $(\mathrm{cm})$, number of branches/plant, number of pods/plant, number of seeds/plant, 100-seed weight and total yield $(\mathrm{kg} / \mathrm{fed})$ were recorded. Total crude protein $(\%)$ in chickpea seeds was determined. The previously determined nitrogen of dry seeds was used for calculating total crude protein by multiplying $\mathrm{N}$ - values by 6.25 (A.O.A.C., 2000).

Statistical analysis:

Analyses of variance were carried out using MSTATC, 1991 program ver. 2.10. Least significant difference was employed to test for significant difference between treatments at $\mathrm{p} \leq 0.05$ (Gomez and Gomez, 1984). 


\section{R e s u l t s}

Effect of different concentrations of date palm leaves compost (DPLC) on wilt severity, plant growth and yield parameters:

Results in Table 2 indicate that date palm leaves compost (DPLC) at all tested concentrations suppressed wilt severity caused by $F$. oxysporum in pot experiments compared to control. The efficacy of DPLC for controlling wilt was increased by increasing concentrations up to 8 ton /feddan then decreased at 10 ton/feddan. The application of DPLC at 8 ton/feddan recorded the lowest wilt severity while; the application of 2 ton/feddan recorded the highest wilt severity caused by $F$. oxysporum.

Also, the results of field experiment indicate that increasing the tested rates of DPLC from 2 to 10 ton /feddan significantly reduced the severity percentage of faba bean wilt (Table 3). The lowest wilt severity in faba bean plants was achieved by using DPLC at 8 ton/feddan. The obtained data also, indicate that addition the DPLC to soil significantly increased all growth and yield parameters, viz. plant height, number of branches, pods and seeds per plant, total seed yield/feddan and seed index (weight of 100- seeds) of faba bean under field conditions at all the tested concentrations compared to control. While protein content in seeds was not significantly affected with DPLC. Application of DPLC at 8 ton/feddan recorded the highest values of plant growth and yield parameters, while using 2 ton DPLC /feddan recorded the lowest values of these characteristics.

Table 2. Effect of different concentrations of date palm leaves compost (DPLC) on wilt severity caused by $F$. oxysporum in pots

\begin{tabular}{|c|c|}
\hline DPLC concentrations (Ton) & \% Wilt severity \\
\hline 2 & $70.1 \mathrm{~b}$ \\
\hline 4 & $52.4 \mathrm{c}$ \\
\hline 6 & $48.6 \mathrm{~d}$ \\
\hline 8 & $45.2 \mathrm{e}$ \\
\hline 10 & $52.7 \mathrm{c}$ \\
\hline Control & $77.2 \mathrm{a}$ \\
\hline
\end{tabular}

Different letters indicate significant differences among treatments within the same column according to the least significant difference test $(\mathrm{P} \leq 0.05)$. 
Table 3. Effect of different concentrations of date palm leaves compost (DPLC) on faba bean wilt severity under field conditions during 2013-2014 growing season

\begin{tabular}{|c|c|c|c|c|c|c|c|c|}
\hline $\begin{array}{c}\text { Date palm } \\
\text { leaves } \\
\text { compost } \\
\text { (DPLC) } \\
\text { concentrations } \\
\text { (Ton/ Fed.) }\end{array}$ & 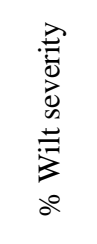 & 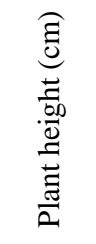 & 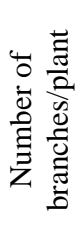 & 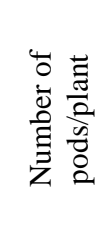 & 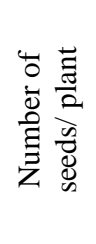 & 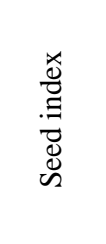 & 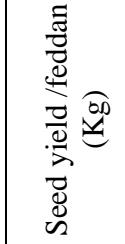 & $\begin{array}{l}\cdot \frac{0}{0} \\
\frac{0}{0} \\
0 \\
0\end{array}$ \\
\hline 2 & $44.2 \mathrm{~b}$ & $75.6 \mathrm{~d}$ & $\begin{array}{c}2.8 \\
b\end{array}$ & $12.9 \mathrm{c}$ & $31.4 \mathrm{~d}$ & $73.6 \mathrm{c}$ & $1299.3 \mathrm{~d}$ & $27.6 \mathrm{a}$ \\
\hline 4 & $40.4 \mathrm{c}$ & $78.9 \mathrm{c}$ & $3.1 \mathrm{a}$ & $13.4 \mathrm{~b}$ & $32.4 \mathrm{c}$ & $74.6 \mathrm{bc}$ & $1325.6 \mathrm{c}$ & $28.1 \mathrm{a}$ \\
\hline 6 & $36.7 \mathrm{~d}$ & $81.4 \mathrm{~b}$ & $3.2 \mathrm{a}$ & $13.7 \mathrm{ab}$ & $35.4 \mathrm{~b}$ & $75.3 \mathrm{~b}$ & $1399.6 \mathrm{~b}$ & $27.8 \mathrm{a}$ \\
\hline 8 & $28.7 \mathrm{e}$ & $84.9 \mathrm{a}$ & $3.3 \mathrm{a}$ & $14.2 \mathrm{a}$ & $36.5 \mathrm{a}$ & $77.1 \mathrm{a}$ & $1455.2 \mathrm{a}$ & $27.6 \mathrm{a}$ \\
\hline 10 & $43.9 \mathrm{~b}$ & $84.2 \mathrm{a}$ & $3.3 \mathrm{a}$ & $14.1 \mathrm{a}$ & $36.4 \mathrm{a}$ & $77.0 \mathrm{a}$ & $1445.6 \mathrm{a}$ & $27.6 \mathrm{a}$ \\
\hline Control & $67.2 \mathrm{a}$ & $69.2 \mathrm{e}$ & $2.2 \mathrm{c}$ & $12.8 \mathrm{c}$ & $29.1 \mathrm{e}$ & $72.0 \mathrm{~d}$ & $1168.3 \mathrm{e}$ & $27.4 \mathrm{a}$ \\
\hline
\end{tabular}

Different letters indicate significant differences among treatments within the same column according to least significant difference test $(\mathrm{P} \leq 0.05)$.

Effect of soil amendment with date palm leaves compost (DPLC) alone or in combination with PGPR strains on wilt severity under greenhouse conditions:

Data presented in Table 4 show that all treatments significantly reduced wilt severity caused by $F$. oxysporum compared with untreated control in pots. Application of mixed plant growth promoting rhizobacteria reduced wilt severity more than those used alone. Plant growth promoting rhizobacteria increased the efficacy of DPLC for controlling wilt disease in faba bean more than the application of DPLC alone. Date palm leaves compost in combination with mixed PGPR strains recorded the lowest wilt severity followed by Ps+DPLC, while DPLC treatment recorded the lowest ones in this respect.

Table 4. Effect of date palm leaves compost (DPLC) alone or combined with PGPR on wilt severity under artificial infestation with $F$. oxysporum in pots.

\begin{tabular}{|l|c|}
\hline \multicolumn{1}{|c|}{ Treatment } & \% Wilt severity \\
\hline \hline Bacillus megaterium (Bm) & $24.29 \mathrm{~d}$ \\
\hline \hline Bacillus cereus (Bc) & $28.49 \mathrm{c}$ \\
\hline \hline Pseudomonas fluorescens (Ps) & $15.47 \mathrm{~h}$ \\
\hline \hline Bm+ Bc+Ps & $12.48 \mathrm{~g}$ \\
\hline \hline Date palm leaves compost (DPLC) & $44.23 \mathrm{~b}$ \\
\hline \hline DPLC+Bm & $18.36 \mathrm{f}$ \\
\hline \hline DPLC+Bc & $22.14 \mathrm{e}$ \\
\hline \hline DPLC+Ps & $10.49 \mathrm{i}$ \\
\hline \hline DPLC+ Bm+ Bc+Ps & $6.59 \mathrm{j}$ \\
\hline \hline Control & $70.25 \mathrm{a}$ \\
\hline
\end{tabular}

Different letters indicate significant differences among treatments within the same column according to least the significant difference test $(\mathrm{P} \leq 0.05)$. 
Effect of soil amendment with date palm leaves compost (DPLC) alone or in combination with PGPR strains on wilt severity and nodulation of faba bean under Field conditions:

Data presented in Table 5 show that all treatments significantly decreased wilt severity compared with untreated control in both growing seasons. The mixed PGPR was more effective than using each of them alone. The decrease of wilt severity was much higher and significantly greater in the presence of date palm leaves compost (DPLC). Moreover, mixed application of DPLC and PGPR was more effective than DPLC alone. The mixture of PGPR strains combined with DPLC recoded the lowest wilt severity in both growing seasons.

Also, application of PGPR strains individually or mixed with DPLC significantly increased the number and dry weight of nodules per plant compared with control in both growing seasons. Mixed application of PGPR and DPLC was more effective for increasing number and dry weight of nodules per plant than compost alone. The highest number of nodules per plant was recorded when faba bean seeds were treated with PGPR mixture and amendment the soil with DPLC, being 188.33 and 169.33 in both seasons, respectively. Also, this treatment recorded the highest dry weight of nodules per plant, being 0352 and $0.342 \mathrm{gm}$ in both seasons, respectively.

Table 5. Effect of date palm leaves compost (DPLC) alone or combined with PGPR on wilt severity and nodulation under field conditions during 2014-2015 and 2015-2016 growing seasons

\begin{tabular}{|c|c|c|c|c|c|c|}
\hline \multirow[b]{2}{*}{ Treatment } & \multicolumn{3}{|c|}{ Season 2014-2015 } & \multicolumn{3}{|c|}{ Season 2015-2016 } \\
\hline & 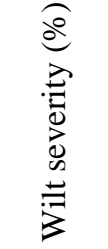 & 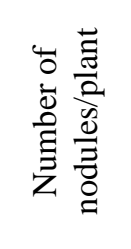 & 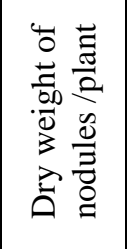 & 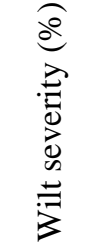 & 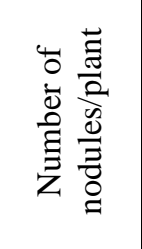 & 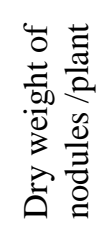 \\
\hline Bacillus megaterium (Bm) & $25.9 \mathrm{f}$ & $123.33 \mathrm{f}$ & $0.243 \mathrm{f}$ & $28.9 \mathrm{e}$ & $115.33 \mathrm{~g}$ & $0.235 \mathrm{~g}$ \\
\hline Bacillus cereus $(\mathrm{Bc})$ & $36.8 \mathrm{~b}$ & $120.00 \mathrm{f}$ & $0.229 \mathrm{~g}$ & $40.2 \mathrm{~b}$ & $109.67 \mathrm{~h}$ & $0.215 \mathrm{i}$ \\
\hline Pseudomonas fluorescens (Ps) & $29.8 \mathrm{~d}$ & $136.67 \mathrm{e}$ & $0.255 \mathrm{e}$ & $22.7 \mathrm{f}$ & $130.67 \mathrm{f}$ & $0.242 \mathrm{f}$ \\
\hline $\mathrm{Bm}+\mathrm{Bc}+\mathrm{Ps}$ & $16.4 \mathrm{~g}$ & $149.33 \mathrm{~d}$ & $0.280 \mathrm{~d}$ & $17.4 \mathrm{~h}$ & $142.00 \mathrm{bc}$ & $0.274 \mathrm{~d}$ \\
\hline $\begin{array}{l}\text { Date palm leaves compost } \\
\text { (DPLC) }\end{array}$ & $36.4 \mathrm{c}$ & $122.33 f$ & $0.233 \mathrm{~g}$ & $38.7 \mathrm{c}$ & $118.67 \mathrm{~g}$ & $0.229 \mathrm{~h}$ \\
\hline DPLC+Bm & $30.2 \mathrm{~d}$ & $156.00 \mathrm{~b}$ & $0.299 \mathrm{~b}$ & $21.4 \mathrm{~g}$ & $142.67 \mathrm{c}$ & $0.281 \mathrm{c}$ \\
\hline $\mathrm{DPLC}+\mathrm{Bc}$ & $27.8 \mathrm{e}$ & $146.67 \mathrm{~d}$ & $0.255 \mathrm{e}$ & $30.5 \mathrm{~d}$ & $135.67 \mathrm{e}$ & $0.249 \mathrm{e}$ \\
\hline DPLC+Ps & $17.8 \mathrm{~g}$ & $153.33 \mathrm{c}$ & $0.293 \mathrm{c}$ & $15.8 \mathrm{i}$ & $145.67 \mathrm{~b}$ & $0.291 \mathrm{~b}$ \\
\hline $\mathrm{DPLC}+\mathrm{Bm}+\mathrm{Bc}+\mathrm{Ps}$ & $12.4 \mathrm{~h}$ & $188.33 \mathrm{a}$ & $0.352 \mathrm{a}$ & $17.5 \mathrm{j}$ & $169.33 \mathrm{a}$ & $0.342 \mathrm{a}$ \\
\hline Control & $57.4 \mathrm{a}$ & $88.33 \mathrm{~g}$ & $0.156 \mathrm{~h}$ & $58.7 \mathrm{a}$ & $70.67 \mathrm{i}$ & $0.144 \mathrm{j}$ \\
\hline
\end{tabular}

Different letters indicate significant differences among treatments within the same column according to the least significant difference test $(\mathrm{P} \leq 0.05)$. 
Effect of soil amendment with DPLC alone or in combination with PGPR strains on plant growth and yield parameters of faba bean under field conditions:

The treatments tested significantly improved plant height and increased number of branches, pods and seeds/ plant, weight of 100 seeds, total seed yield, dry seed content of protein compared with check treatment during the two experimental seasons (Tables 6 and 7). When seeds were treated with mixture of PGPR strains before planting all growth and yield tested parameters were more increased than seeds treated with each of them alone in both growing seasons. Also, application of PGPR mixed strains together with DPLC increased growth and yield parameters more than DPLC alone. Faba bean treated with mixed PGPR strains and soil amendment with DPLC at 8 ton/feddan recorded the highest plant height, and increased number of branches, pods and seeds /plant, weight of 100 seeds, total seed yield, dry seed content of protein in both growing seasons.

Table 6. Effect of date palm leaves compost (DPLC) alone or combined with PGPR on plant growth and yield parameters of faba bean under field conditions during 2014-2015 growing season

\begin{tabular}{|c|c|c|c|c|c|c|c|}
\hline Treatment & 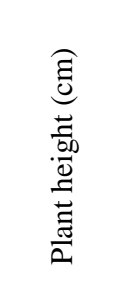 & 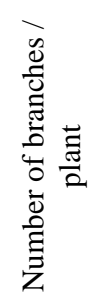 & 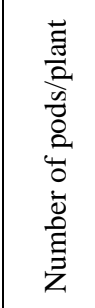 & 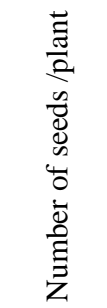 & 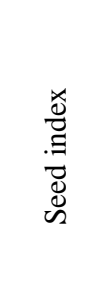 & 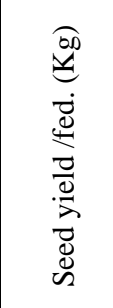 & $\begin{array}{l}\text { : } \\
0 \\
0 \\
0 \\
0\end{array}$ \\
\hline Bacillus megaterium $(\mathrm{Bm})$ & 99.3de & $3.1 \mathrm{~cd}$ & $15.3 \mathrm{c}$ & 42.3de & $80.2 \mathrm{~d}$ & $1498.6 \mathrm{f}$ & $27.6 \mathrm{~b}$ \\
\hline Bacillus cereus $(\mathrm{Bc})$ & $85.3 f$ & $2.9 \mathrm{~d}$ & $14.2 \mathrm{~d}$ & $39.6 \mathrm{e}$ & $77.9 f$ & $1457.2 \mathrm{~g}$ & $28.3 \mathrm{a}$ \\
\hline Pseudomonas fluorescens (Ps) & $102.3 \mathrm{~d}$ & $3.3 \mathrm{c}$ & $16.9 \mathrm{bc}$ & $44.6 \mathrm{~d}$ & $82.3 \mathrm{bc}$ & $1593.6 \mathrm{~d}$ & $27.9 \mathrm{ab}$ \\
\hline $\mathrm{Bm}+\mathrm{Bc}+\mathrm{Ps}$ & $114.5 \mathrm{bc}$ & $3.6 \mathrm{~b}$ & $18.4 \mathrm{~b}$ & $51.4 \mathrm{~b}$ & $82.9 \mathrm{bc}$ & 1623.2 & $28.5 \mathrm{a}$ \\
\hline $\begin{array}{l}\text { Date palm leaves compost } \\
\text { (DPLC) }\end{array}$ & $83.6 f$ & $3.2 \mathrm{~cd}$ & $13.5 \mathrm{e}$ & $35.6 f$ & $76.6 \mathrm{~g}$ & $1352.2 \mathrm{~h}$ & $27.3 \mathrm{bc}$ \\
\hline $\mathrm{DPLC}+\mathrm{Bm}$ & $112.3 \mathrm{~d}$ & $3.3 \mathrm{c}$ & $17.6 \mathrm{~b}$ & $48.9 \mathrm{c}$ & $82.1 \mathrm{c}$ & $1563.2 \mathrm{~d}$ & $27.6 \mathrm{~b}$ \\
\hline$\overline{\mathrm{DPLC}+\mathrm{Bc}}$ & $96.7 \mathrm{e}$ & $3.1 \mathrm{~cd}$ & $15.9 \mathrm{c}$ & $43.2 \mathrm{~d}$ & $79.3 \mathrm{e}$ & $1488.6 f$ & $28.3 \mathrm{a}$ \\
\hline $\mathrm{DPLC}+\mathrm{Ps}$ & $119.3 b$ & $3.5 b c$ & $18.6 \mathrm{~b}$ & $50.8 \mathrm{~b}$ & $83.3 b$ & $1655.8 \mathrm{~b}$ & $28.4 \mathrm{a}$ \\
\hline $\mathrm{DPLC}+\mathrm{Bm}+\mathrm{Bc}+\mathrm{Ps}$ & $134.6 \mathrm{a}$ & $4.2 \mathrm{a}$ & $22.2 \mathrm{a}$ & $63.2 \mathrm{a}$ & $85.6 \mathrm{a}$ & $1745.4 a$ & $28.7 a$ \\
\hline Control & $74.3 \mathrm{~g}$ & $2.4 \mathrm{e}$ & $11.2 \mathrm{f}$ & $28.3 \mathrm{~g}$ & $74.5 \mathrm{~h}$ & $1196.2 \mathrm{j}$ & $26.9 \mathrm{c}$ \\
\hline
\end{tabular}

Different letters indicate significant differences among treatments within the same column according to least significant difference test $(\mathrm{P} \leq 0.05)$.

Egypt. J. Phytopathol., Vol. 45, No. 1 (2017) 
Table 7. Effect of date palm leaves compost (DPLC) alone or combined with PGPR seed treatments on plant growth and yield parameters of faba bean under field conditions during 2015-2016 growing season

\begin{tabular}{|c|c|c|c|c|c|c|c|}
\hline Treatment & 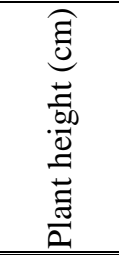 & 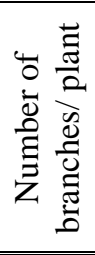 & 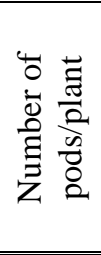 & 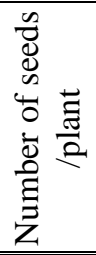 & 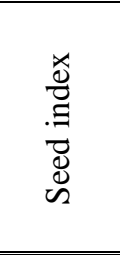 & 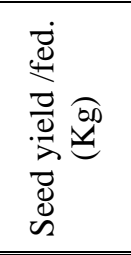 & $\begin{array}{c}\cdot= \\
\frac{0}{0} \\
0 \\
0 \\
0\end{array}$ \\
\hline B. megaterium $(\mathrm{Bm})$ & $95.3 \mathrm{e}$ & $2.9 \mathrm{~cd}$ & $15.2 \mathrm{~d}$ & $44.3 \mathrm{e}$ & $81.0 \mathrm{c}$ & $1469.8 \mathrm{e}$ & $27.9 \mathrm{ab}$ \\
\hline B. cereus $(\mathrm{Bc})$ & $82.3 \mathrm{~h}$ & $2.8 \mathrm{~d}$ & $13.6 \mathrm{f}$ & $38.9 \mathrm{~g}$ & $78.3 \mathrm{~d}$ & $1472.3 \mathrm{e}$ & $28.4 \mathrm{a}$ \\
\hline P. fluorescens (Ps) & $99.3 \mathrm{~d}$ & $3.1 \mathrm{c}$ & $17.2 \mathrm{c}$ & $45.2 \mathrm{e}$ & $83.5 \mathrm{a}$ & $1602.1 \mathrm{c}$ & $28.1 \mathrm{a}$ \\
\hline $\mathrm{Bm}+\mathrm{Bc}+\mathrm{Ps}$ & $115.2 \mathrm{~b}$ & $3.5 \mathrm{~b}$ & $18.6 \mathrm{~b}$ & $50.3 \mathrm{c}$ & $83.5 \mathrm{a}$ & $1624.1 \mathrm{c}$ & $28.3 \mathrm{a}$ \\
\hline $\begin{array}{l}\text { Date palm leaves } \\
\text { compost (DPLC) }\end{array}$ & $84.1 \mathrm{~g}$ & $3.3 \mathrm{bc}$ & $13.5 \mathrm{f}$ & $33.5 \mathrm{~h}$ & $75.4 \mathrm{e}$ & $1342.9 f$ & $27.6 \mathrm{c}$ \\
\hline DPLC+Bm & $111.0 \mathrm{c}$ & $3.3 \mathrm{bc}$ & $17.2 \mathrm{c}$ & $48.6 \mathrm{~d}$ & $83.2 \mathrm{ab}$ & $1549.8 \mathrm{~d}$ & $27.4 \mathrm{c}$ \\
\hline $\mathrm{DPLC}+\mathrm{Bc}$ & $93.5 \mathrm{f}$ & $3.0 \mathrm{c}$ & $14.6 \mathrm{e}$ & $42.9 \mathrm{f}$ & $78.4 \mathrm{~d}$ & $1463.5 \mathrm{e}$ & $27.9 \mathrm{ab}$ \\
\hline $\begin{array}{l}\text { DPLC+Ps } \\
\end{array}$ & $116.2 \mathrm{~b}$ & $3.6 \mathrm{~b}$ & $18.4 \mathrm{~b}$ & $52.1 \mathrm{~b}$ & $82.6 \mathrm{ab}$ & $1658.3 \mathrm{~b}$ & $28.1 \mathrm{a}$ \\
\hline $\begin{array}{l}\mathrm{DPLC}+\mathrm{Bm}+ \\
\mathrm{Bc}+\mathrm{Ps}\end{array}$ & $133 \mathrm{a}$ & $4.1 \mathrm{a}$ & $21.5 \mathrm{a}$ & $61.4 \mathrm{a}$ & $84.2 \mathrm{a}$ & $1715.6 \mathrm{a}$ & $28.3 \mathrm{a}$ \\
\hline Control & $71.6 \mathrm{i}$ & $2.3 \mathrm{e}$ & $11.4 \mathrm{~g}$ & $27.4 \mathrm{i}$ & $72.9 \mathrm{f}$ & $1152.3 \mathrm{~g}$ & $27.3 \mathrm{c}$ \\
\hline
\end{tabular}

Different letters indicate significant differences among treatments within the same column according to least significant difference test $(\mathrm{P} \leq 0.05)$.

\section{D i s c u s s i o n}

Faba bean (Vicia faba L.) is one of the most important legume crops. It is liable to infection with many fungal pathogens causing considerable yield losses. Root-rot and wilt diseases are the most important fungal diseases affecting faba bean production in Egypt (Abdel-Kader et al., 2011 and Abdel- Monaim, 2013 and 2017). Soil-borne fungal plant pathogens are among the major factors limiting the productivity of agroecosystems and are often difficult to control with conventional strategies such as the use of resistant host cultivars and synthetic fungicides. The lack of reliable chemical control, the occurrence of fungicide resistance in pathogens, and the breakdown or circumvention of host resistance by pathogen populations (McDonald and Linde, 2002) are some of the reasons underlying efforts to develop new disease control measures.

In this context, the search for alternatives with high efficiency, low cost and limited environmental impact is a challenge for eco-sustainable modern agriculture. In the research for alternatives to chemical treatments, biological control may be a useful tool (El-Wakil et al., 2009). Soil amendment with compost is an agronomically increasing practice and it favours plant development and improves soil quality, as well as having suppressive effect on many soil-borne plant pathogenic fungi (El-Wakil et al., 2009 and Abdel-Razik et al., 2012). Faba bean plants grown in soil artificially infested with $F$. oxysporum in the greenhouse also under the natural infection in the field and supplemented with date palm leaves compost (DPLC) at rates equivalent to 2,4,6,8 and

Egypt. J. Phytopathol., Vol. 45, No. 1 (2017) 
10 ton/feddan have a suppressive effect on the severity of wilt. Also, adding DPLC in the field experiments increased plant growth and yield parameters compared with control. Date palm leaves compost at 8 ton/feddan recorded the highest protection against $F$. oxysporum in pots and in field experiments as well as improved plant growth and yield parameters in field. Such results confirm the previous reports indicating that composted soil has the potential to protect different plants from soil-borne root pathogens such as Rhizoctonia solani and different species of Fusarium in faba bean and other crops (Abdel-Razik et al., 2012 and Abo-Elyousr et al., 2014) and to promote growth and yield of faba bean plants by improving soil chemical, physical and biological properties (El-Wakil et al., 2009). This may be due to changes in the overall population of the antagonistic resident soil bacteria and fungi which compete with the pathogens as well as changes in the amount and availability of soil nutrients to plants associated with CMs application as mentioned by Abo-Elyousr et al. (2014). Aryantha and Guest (2006) reported that the beneficial effects induced by composts are due to increase the activities of soil microbes in the plant rhizosphere. Some of them produce plant growth hormones and stimulate plant growth directly, while others produce natural chelators called siderophores that keep iron at a high level in available form to plant in soil.

The suppressive effect of compost is due to combination of biotic factors. The biotic factor including the inhabiting microbes (bio-agents), viz. plant growth promoting rhizobacteria strains (B. megaterium, B. cereus and $P$. fluorescens) is might be partly responsible for the efficacy of compost in decreasing soil borne diseases (Nawar, 2008). Moreover, application of PGPR stains in combination with compost led to increase the plant resistance to diseases through utilization of these bio agents in increasing synthesis of phenolic and ligneous compounds. This may explain the high decrease in disease incidence in mixed treatments.

Therefore, in the present research great efforts were made to know the effect of PGPR strains individually or combined with DPLC at 8 ton/feddan in soil artificially infested with $F$. oxysporum under greenhouse, and natural infection with soil borne pathogens under field conditions as well as plant growth and yield parameters. The obtained data indicate that all PGPR strains and DPLC individually or in combination significantly decreased wilt severity under greenhouse and field conditions compared with control. Also, these treatments improved plant growth (plant height and number of branches /plant) and increased yield parameters (number of pods, seeds /plant, seed index and total yield/feddan) in the field. Application of mixed PGPR strains and DPLC decreased wilt incidence as well as increased plant growth and yield parameters more than using DPLC alone. These results are in agreement with those reported by Pugliese et al. (2011). Abdel-Razik et al. (2012) reported that these bio-control agents could be added to compost to improve disease suppression and reduce the variability. Suppression of wilt could be due the beneficial effect of such microbes in single way or in combination with others on the pathogen and/or the suspect or on the host-parasite interaction may lead to control wilt disease of faba bean. Also, PGPR are able to produce many enzymes such as chitinases and glucanases which are responsible for Egypt. J. Phytopathol., Vol. 45, No. 1 (2017) 
suppression of the plant pathogen. These enzymes function by breaking down the polysaccharides, chitin, and $\beta$-glucanase that are responsible for the rigidity of fungal cell walls, thereby destroying cell wall integrity (Termorshuizen et al., 2006).

\section{Conclusion}

In conclusion, using of mixed PGPR, viz. B. megaterium, B. cereus, P. fluorescens alone or in combination with date palm leaves compost can be recommend for controlling Fusarium wilt of faba bean under greenhouse and field conditions and may be a useful tool for improvement of plant growth and yield components in field.

\section{Ref e r e n e s}

A.O.A.C. 2000. Official Methods of Analysis Association of Official Analysis Chemists. $25^{\text {th }}$ Ed., AOAC, Washington D.C., USA.

Abdel-Kader, M.M.; El-Mougy, Nehal, S. and Lashin, S.M. 2011. Essential oils and Trichoderma harzianum as an integrated control measure against faba bean root rot pathogens. J. Plant Prot. Res., 51:306-13.

Abdel-Monaim, M.F. 2013. Improvement biocontrol of damping-off and root rot/wilt of faba bean by salicylic acid and hydrogen peroxide. Mycobiol., 41(1):47-55.

Abdel-Monaim, M.F. 2017. Evaluation of the accumulation of pathogenesis related (PR) proteins and phenolic compounds in response to biotic and abiotic elicitors as mechanism for immune response to Fusarium wilt disease in faba bean. J. Plant Pathol. Microbiol., 8(2): 1-8.

Abdel-Razik, Sahar, A.; Sallam, Nashwa. M.A.; Eraky Amal, M.I. and Hassan, M.H. A. 2012. Integrated control of root rot and wilt diseases of faba bean by soil amendment with suppressive compost in combination with seed coating with an antagonistic yeast. Archives Phytopathol. Plant Prot., 45(14): 1692-1704.

Abo-Elyousr, K.A.M.; Zein El-Abdean, W.; Hassan, M.H.A. and El-Sheakh, M.M. 2014. Enhance suppressive effect of compost on soybean Rhizoctonia root rot by soil treatment with Trichoderma harzianum. J. Plant Physiol. Pathol., 2(2):1-6.

Abu-Alfadhal, M.M. 1970. Organic Manures. $1^{\text {st }}$ Ed., Al-Saadah Publishers, Cairo, Republic of Egypt, Egypt.

Ali, Y.S.S. 2011. Effect of mixing date palm leaves compost (DPLC) with vermiculite, perlite, sand and clay on vegetative growth of dahlia (Dahlia pinnata), marigold (Tagetes erecta), zinnia (Zinnia elegans) and cosmos (Cosmos bipinnatus) Plants. Res. J. Environ. Sci., 5: 655-665.

Aryantha, N.P. and Guest, D.I. 2006. Mycoparasitic and antagonistic inhibition on Phytophthora cinnamomi rands by microbial agents isolated from manure composts. Plant Pathol. J., 5(3):291-298.

Bonanomi, G., Antignani V., Pane, C. and Scala, F. 2007. Suppression of soilborne fungal diseases with organic amendments. J. Plant Pathol., 89 (3): 311-324.

Egypt. J. Phytopathol., Vol. 45, No. 1 (2017) 
El-Bramawy, M.A.S, and Shaban, W.I. 2010. Effects of potassium fertilization on agronomic characters and resistance to chocolate spot and rust diseases in faba bean. Tunisian J. Plant Prot., 5(2): 131-150.

El-Mougy, Nehal, S.; Abdel-Kader, M.M. and Abdel-Kareem, F. 2014. Application of commercial composts and/or Trichoderma harzianum for controlling lupine root rot disease under field conditions. Int. J. Engin. Innovative Technol., 4(2): 68-73.

El-Wakil, M.A.; El-Refai, I.M.; Awadallah, O.A.; El-Metwally, M.A. and Mohammed, M.S. 2009. Seedborne pathogens of faba bean in Egypt: detection and pathogencity. Plant Pathol. J., 8:90-97.

Fernández, M.M.; López-Jurado, M.; Aranda, P. and Urbano, G. 1996. Nutritional assessment of raw and processed faba bean (Vicia faba L.) cultivar major in growing rats. J. Agric. Food Chem., 44(9): 2766-2772.

Gomez, K. A. and Gomez A. A. 1984. Statistical Procedures for Agricultural Research. New York: A Wiley-Interscience Publication.

Heydari, A. and Pessarakli, M. 2010. A Review on Biological Control of Fungal Plant Pathogens Using Microbial Antagonists. J. Biological Sci., 10: 273-290.

Hoitink, H.A.J. and Boehm, M.J. 1999. Biocontrol within the context of soil microbial communities: a substrate dependent phenomenon. Annu. Rev. Phytopathol., 37:427446.

Litterick, A. M.; Harrier, L.; Wallace, P.; Watson, C. A. and Wood, M. 2004. The role of uncomposted materials, composts, manures, and compost extracts in reducing pest and disease incidence and severity in sustainable temperate agricultural and horticultural crop production-A review, Critical Rev. in Plant Sci., 23 (6): 453-479.

Liu, L.; Kloepper, J.W. and Tuzun, S. 1995. Induction of systemic resistance in cucumber against Fusarium wilt by plant growth-promoting Rhizobacteria. Phytopathology, 85:695-698.

Mahmoud, A.F. 2016. Evaluation of certain antagonistic fungal species for biological control of faba bean wilt disease incited by Fusarium oxysporum. J. Phytopathol. Pest Manag., 3(2): 1-14.

McDonald, B. A. and Linde, C. 2002. Pathogen population genetics, evolutionary potential, and durable resistance. Annu. Rev. Phytopathol., 40: 349-379.

Muhammad, S.; Suberu, H.A.; Amusa, N.A. and Agaji, M.D. 2001. Seedling blight of Tamarrindus indica Linn caused by Macrophomina phaseolina and Rhizoctonia solani. Moor J. Agric. Res., 2:40-46.

Nawar, L.S. 2008. Control of root-rot of green been with composted rice straw fortified with Trichoderma harzianum. American-Eurasian J. Agric. Environ. Sci., 3:370 379 .

Egypt. J. Phytopathol., Vol. 45, No. 1 (2017) 
Pugliese, M.; Liu, B.; Gullino, L.M. and Garibaldi, A. 2011. Microbial enrichment of compost with biological control agents to enhance suppressiveness to four soilborne diseases in greenhouse. J. Plant Dis. Protec., 118: 45-50.

Sabet, K. K.; Saber, M. M; El-Naggar, M. A.; El-Mougy, Nehal, S.; El-Deeb, H. M. and El-Shahawy, I.E. 2013. Using commercial compost as control measures against cucumber root-rot disease. J. Mycol., 13:1-12.

Termorshuizen, A.J.; van Rijn E., Van der Gaag, D.J.; Alabouvette, C.; Chen, Y.; Lagerlöf, J.; Malandrakis, A.A.; Paplomatas, E.J.; Rämert B.; Ryckeboer, J.; Steinberg, C. and Zmora-Nahum, S. 2006. Suppressiveness of 18 composts against 7 pathosystems: variability in pathogen response. Soil Biology \& Biochemistry, 38:2461-2477.

(Received 19/04/2017;

in revised form 25/05/2017) 


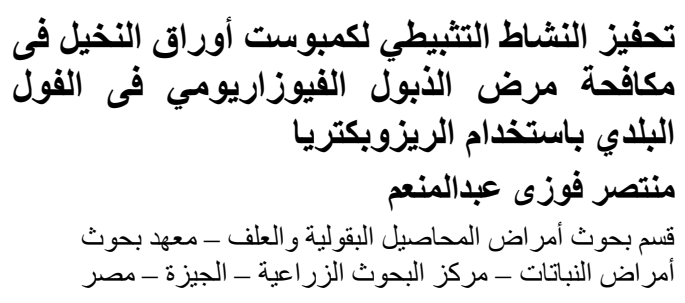

يعتبر كمبوست أوراق النخيل من الأسمدة العضوية المُنتجة حديثاً بمحافظة

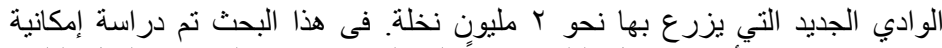

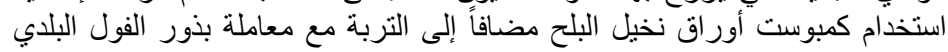

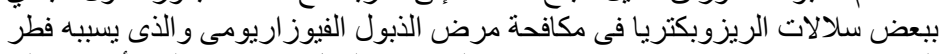

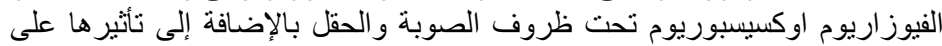
بعض صفات النمو و المحصول.

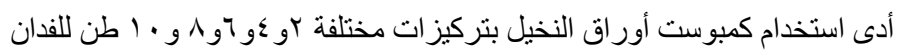

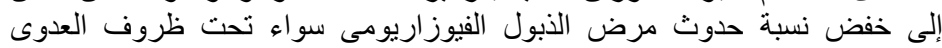

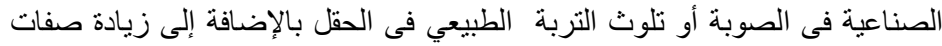

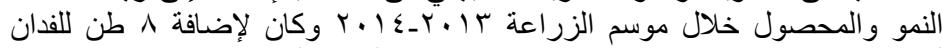

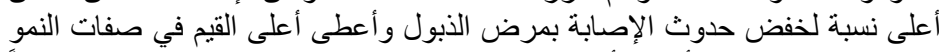

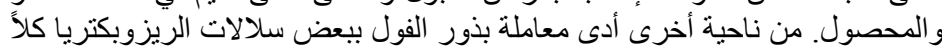

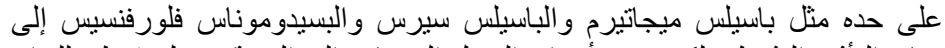

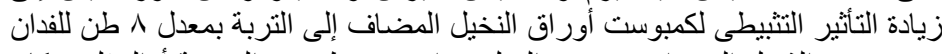

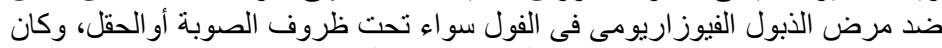

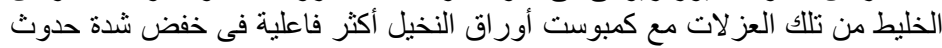

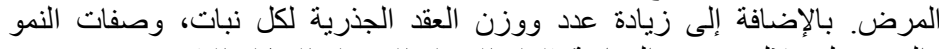

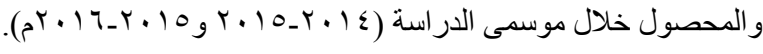

